\title{
Application and Personalized Performance of Ecological Idea in Environmental Art Design
}

\author{
Zhang Wei \\ Jiangxi Institute of Fashion Technology
}

Keywords: Ecological idea; Environmental art design; Application; Personalization; performance

\begin{abstract}
Social development and progress accelerate the growth in the living standard and stimulate people's spiritual needs. Especially on the aspect of environmental art design, people tend to pay more and more attention to the guidance of ecological idea for promoting environmental protection. This text proceeds from environmental art design to probe into application principle and significance of ecology theory in environmental art design and then further analyze its application and personalized performance in environmental art design.
\end{abstract}

\section{Introduction}

Having an increasing demand with social development and human progress, people keep exploiting and developing the nature constantly, striving to gain more economic benefits and interests. Particularly industrial development brings about many environmental problems such as air pollution and water pollution which act as a severe threat to the living space of people who gradually begin to regret their errors and hope to save and remedy crises through the efforts from each aspect. Application of ecological idea in environmental art design is of help to provoke people's reflection on the environment so as to deepen the nation's awareness of environmental protection.

\section{Connotation of Environmental Art Design}

Environmental art design is a kind of design made towards architectural space and environment by virtue of particular artistic methodology and means and urban planning and design, architecture and interior design, ecological garden and landscape design all belong to environmental art design which possesses strong comprehensiveness and is the spatial planning for entire art project, including environment and facilities plan, space and decoration project, modeling and construction plan, material and color scheme, illumination and lighting plan, plan for use function and aesthetic function and so on.

Possessing features such as integrality, diversity, humanity and technicality, environmental art design cultivates people's sentiment and satisfies their use function and aesthetic function towards architectural space through these features. Thus, environmental art design is a dynamic integration of three aspects, environment, art and design.

\section{Application Principle of Ecological Idea in Environmental Art Design}

Science and Technology as the Guidance. Nowadays, the level of science and technology is an important sign of comprehensive national strength of a country. The development of science and technology promotes continuous improvement of the society. Moreover, science and technology solve many problems for us, offering more convenience to our life. In the process of making environmental art designs, science and technology should be regarded as the guidance. Advanced science, technology and new environmental protection materials should be utilized to create artistic environment with high quality so as to improve people's living standards and serve the society. Thus, under the guidance of science and technology, environmental art design should apply advanced, 
scientific and environmental materials in the designing scheme, and convey ecological idea to each aspect of design.

Artistic Design as the Subject. Environmental art design is a new subject content and artistic reform of ecological environment, and a constant pursuit of beauty. Environment doe not exist alone but it is an integral whole formed by combined action of various external factors. Environment is the space for people to live. It is human nature to pursue beauty. With the continuous improvement of living standard, people have a higher and higher pursuit of beauty. In addition, artistic development is speeding up, and art is frequently applied in every aspect of social life. Environmental art design is exactly the fruit of unceasing application of art in environmental design and thus it has gradually become a unique artistic discipline. Therefore, artistic design should be regarded as the subject when ecological idea is integrated into environmental art design to create an environment with both artistic charm and ecological idea.

4R Principle. 4R principle refers to the low-carbon principle, i.e., Reduce, Reuse, Recycle and Recovery, which raises high request for stylists on environmental art design. Low-carbon lifestyle has become the theme of people's life at present. The addition of ecological idea to environmental art design meets the requirement of social development. Thus, significance of environmental protection should be taken into consideration in designing and low-carbon environmental raw materials or recyclable materials should be utilized to reduce resource consumption and improve resourceutilization-rate. Moreover, 4R principle should be followed practically to carry ecological idea through designing scheme.

\section{Significance of Ecological Idea in Environmental Art Design}

Application of ecological idea in environmental art design could increase the environmental awareness of people and help to better protect the natural environment in which we live. As the space environment for the survival of mankind, natural environment has effect on survival and living quality of people. Human beings severely destroy the natural environment when doing producing activities. Moreover, as time goes on, human's exploitation and utilization of nature has already exceeded the recovery ability of nature and brought about many environmental problems such as haze and greenhouse effect. The appearance of ecological idea bears significant meaning to reconcile the contradiction between human and nature. As a result, utilization of ecological idea in environmental art design is an objective requirement of social development.

Demand of Environment. Social development brings progresses for human beings and inevitable environmental problems in the meantime. In recent years, many disasters brought by destruction of the environment have already seriously threatened people's survival and development. People gradually begin to reflect on their errors and pay more attention to the issue of environmental protection. The awareness of environmental protection has been improved as well.

Demand of Society. Art is the crystallization of human wisdom, sublimation of human consciousness and also the result of constant improvement of living standard and pursuit. Not only artistic value of environment is promoted but also ecological idea is delivered to the people to facilitate the harmony between man and nature so as to reduce the destruction of ecological environment in the process of environmental art design, which is an inevitable demand of social development.

Demand of Art. Art comes from life and goes beyond it. Art is the extraction, purification and sublimation of life and nature. Artists tend to select materials in the natural world and blend their own emotion in these creation resources. Final fruit is the so-called artistic work. Integration of ecological idea into environmental art design is the promotion and improvement of art, and high praise to art as well. 


\section{Application and Personalized Performance in Environmental Art Design}

Different from traditional environmental art design, more attention is paid to environmental protection when ecological idea is integrated into the design. Emphasis should be laid on the contents of following aspects about the application and personalized performance of ecological idea in environmental art design.

Use of Natural or Existing Materials. An important aspect of the application of ecological idea in environmental art design is the selection and use of materials, which requires stylists to know the usages and features of various natural materials and make fully use of their subjective initiative in designing. For example, many trees and flower could be planted in the process of urban planning and design to build a comfortable environment for living. Surely cobblestones could be used to be laid in the construction of the ground to work out beautiful patterns and also bring about functions such as body building and acupoint massage. Besides, there are many abandoned buildings around us. These buildings could be remolded to produce new use value. For instance, abandoned buildings can be reformed to various kinds of art venues and fitness centers so that removal cost is reduced and people's living environment is improved. These measures successfully blend ecological idea into environmental art design and have achieved huge economic and social benefits.

Ecological Design and Protection. Ecological design is to maintain the balanced development of ecological system under the guidance of ecological theory in the process of environmental art design. With the development of society and people's thoughts, ecological and environmental awareness improves constantly and goes deep into all aspects of social life. Adoption of ecological design and protection is helpful to reduce damage to the nature. For example, in the process of urban planning and design, local terrain and rivers shall be investigated comprehensively to formulate an overall arrangement of urban planning so as to reduce people's intervention to natural system, keep original ecological environment as much as possible, guide people with ecological idea and accelerate sustainable development.

Utilization of Natural Environmental Basis. What human beings are very good at is to transform nature and change natural environment completely. Human behaviors have caused severe destruction to natural environment. Thus, natural environmental basis shall be fully utilized in the process of environmental art design. Design is made according to the original terrain and landform. For example, China has complex and diverse topographic and geomorphic conditions which form many unique geomorphologic landscapes. Buildings could be designed according to these unique geomorphologic landscapes. By this way, much cost can be saved and product designed can merge into an organic whole with nature, possessing unique and personalized features and matching the form of surroundings so that integrality of environment gets protected.

Development and Utilization of New Energy Resources. Although energy resources are abundant in China, their distribution is very unequal among different areas. Moreover, many energy resources are not renewable resources but resources with high pollution level. For example, oil and coal resources are indispensable for our life but easy to cause environmental destruction. Therefore, it is necessary to sufficiently develop and utilize new energy resources and alternate resources to reduce environmental destruction in the process of conducting artistic designing of ecological environment. Solar power generation and wind power generation serve as two vivid examples. They are not only landscape resources but also power resources in an area. Both artistic value and use value are contained in these two projects. A win-win situation between economic benefit and social benefit is realized by this way.

\section{Conclusions}

With the rapid development of the contemporary society, attention should not merely be paid to economic development, but also to surrounding ecological environment and living environment, which makes the application of ecological idea in environmental art design becomes a new research 
topic. In the process of making environmental art design, people lay more and more emphasis on the environmental requirement of sustainable development, and frequently utilize ecological idea to satisfy the demand of mankind. Ecological idea has become an important guiding thought for environmental art design.

\section{References}

[1] Li Qi. Discussion on Ecological Concept in Environmental Art Design[J]. Beauty \& Times(City Edition),2015,01:30-31.

[2] Li Weiguang. Ecological Concept in Environmental Art Design[J]. Modern Decoration (Theory),2013,06:140-141.

[3] Wang Ping, Chen Wenfu. Research on Ecological Concept in Environmental Art Design[J].Design Research,2013,05:51-54.

[4] Zhong Xue. Application and Analysis of Ecological Idea in Environmental Art Design[J]. Intelligence,2015,18:296.

[5] Ma Jingjing. Discussion on Ecological Idea in Environmental Art Design[J]. Appreciation,2015,04:73.

[6] Zhou Wei. Ecological design idea of dynamic research [D]. Jilin university, 2013.

[7] Tian GuoXin. The effective ecology in environmental art design concept into [J]. Chinese science, 2015, 11:157.

[8] Li Jing. Secondary vocational art education under the background of the concept of ecological environmental art design study [J]. Journal of arts education research, 2015, 10, 94.

[9] Wang JinRui, liu kewei. Environmental art design concept and its aesthetic characteristics of thinking [J]. Journal of foreign building materials science and technology, 2007,01:92-95.

[10] Liu JianFeng. Environmental art design of the ecological concept to explore [J]. Journal of private science and technology, 2013 preceding: 53.

[11] Ma XiaoMin . Try to talk about environmental art design in the ecological idea [J]. Science and technology, 2013, 226:226.

[12] Qu HanYi. Sustainable development theory in the teaching of environmental art design major application [D]. Harbin normal university, 2014. 